\title{
A SURVEY IN SOWETO (SOUTH WESTERN TOWNSHIP) ON THE AVAILABLE HEALTH SERVICES
}

\author{
JOYCE T. NCALA \\ Tutor, Baragwanath Hospital
}

\section{OPSOMMING}

'n Opname van beskikbare gesondheidsdienste in Soweto is deur telefoniese en persoonlike onderhoude gemaak. Demografiese en sosiaal-ekonomiese inligting oor die gebied, soos oppervlakte, klimaat, bevolking, fasiliteite vir omgewingshigiëne, werksgeleenthede, onderwys en opvoeding word gegee.

Die algemene gesondheidstoestand en -probleme word genoem en daarop volg 'n bespreking van voorkomende, bevorderende, kuratiewe en ondersteunende gesondheidsdienste. Dienste vir bejaardes word spesifiek toegelig.

\section{INTRODUCTION}

Survey research, also known as descriptive research, is the method whereby data is collected, recorded and analysed. ( 8 p 57). The scope of this survey was the health services of Soweto. The purpose was to obtain a complete picture of the community of Soweto; to update knowledge concerning health services in order to teach adequately; and being a citizen of Soweto, data collected is for the good of my family

\section{METHOD}

The method used for collecting data was a survey by telephone and personal interviews with the following:

- the West Rand Administration Board (WRAB) Public Relations Officer;

- the Baragwanath Hospital's Public Relations Officer;

- a Senior Administrator of the Urban Bantu Chambers, Soweto;

- the H use-keeper, Soweto Food Gardc.ss, Mofolo South;

- the Secretary and the Senior Social Worker at Happiness House for the Care of the Aged, Johannesburg;

- the White City Jabavu Methodist and Anglian Church self-help services;

- the Senior Administrator of the Department of Plural Affairs, Johannesburg;

- the Public Relations Officer of the Protea police station, Soweto.

To augment verbal reports, much information was obtained from available books and brochures related to the subject researched, and through subjective observation using the senses of sight, hearing, smell, taste and touch (1, p 67-70).

There were however a few difficulties encountered in obtaining data:

- obtaining exact figures was the main problem with certain interviews - only approximate figures were given;

- telephone discussions were rather too brief;

- there is no register for the voluntary organisations in Soweto - most groups operate in Johannesburg for all citizens.

\section{RESULTS}

\section{Demographic and Socio- Eco- nomic Information}

Soweto is a large area with a diameter of approximately $1440 \mathrm{~km} \mathrm{(3;}$ square miles) and is zoned as a black urban area for all ethnic groups. It is situated about $35 \mathrm{~km}$ south-west of Johannesburg and it takes 15-20 minutes to drive from the city centre to Soweto. Soweto is bordered by secondary urban areas namely, Diepkloof and Noordgesig to the east; farm areas which separate Soweto from the Randfontein area to the west; Dobsonville to the north and Kliptown to the South - Soweto is composed of eighteen areas namely; Chiawelo; Dlamini; Moletsane; Senoane; Tladi; Molopo; Emdeni South; North and Extension; Naledi; Zondi 1 and 2; Central Western Jabavu; White City Jabavu; Rockville; Umzimhlophe; Orlando East and West; Dube; Mofolo Village South and North; Klipspruit; Jabulani and Zola 1, 2 and 3.

The area has a healthy climate which favours outdoor living in all seasons. The mean annual surface temperature ranges between $17,5^{\circ} \mathrm{C}$ and $20^{\circ} \mathrm{C}(6, \mathrm{p} 13)$. Hot summer days are sometimes accompanied by morning and afternoon rains. The soil is fertile because there are flowers, vegetables and peach trees in most yards. The political climate is much better than in 1976-1977. Community councils operate under WRAB and take charge of certain duties according to the Community Councils Act 125 of 1977 (6, p 148)

Soweto is outside the industrial area but there is a big dry cleaning factory under construction near Merafe Station. Soweto Bakery in Orlando is already in operation. The neighbouring farmers supply residents with fresh eggs, poultry, sheep, goats, cattle vegetables, milk, fruit and mealies at reasonable cost

There are two highways between Johannesburg and Soweto. The communication system includes telephones which is a newly available service for anybody who wishes to have a telephone installed. There is also public and private transport. Construction and maintenance of roads and bridges fall under the National Roads Act (54 of 1971) (6, p 141).

Soweto is densely populated with more than a million people. According to the 1980 census the population was 800000 . However, this figure does not agree with the impression of the people and those in authority. The following factors may have contributed to an incorrect figure:

- the misconceptions that some people always have about a census;

- many people stay in Soweto illegally because of influx control;

- most gangsters, as found in all major cities of the world, do not work and therefore hide during the census period; 
- some assistant researchers seemed to be in a hurry, some copied information from house permits;

- it is suspected that there are also many people from Zimbabwe and Mozambique who adopted Zulu surnames and stay in Soweto illegally.

Soweto has mainly sub-economic houses without electricity. Electricity is being installed and it is hoped that by the end of 1981 all houses will be electrified. This will help to prevent the air pollution caused by coal stoves. There are no slum areas if the area is viewed against the Slums Act 66 of 1975 (6, p 145). Some houses are overcrowded - probably as a result of the cultural belief in extended families for moral support. It may not be surprising to find fifteen people living in a four-room house.

To give a complete picture of the socio-economic status of the people of Soweto, is not an easy task. This is difficult for an area with a large number of heterogenous ethnic elements, with different levels of socio-economic development. The inhabitants are however becoming involved in the process of providing adequate housing and thus improving the quality of their lives. The introduction of the 99-years leasehold system in 1978 enables Black people to obtain loans from building societies and other financial institutions against the registration of a bond. The urban Blacks therefore have the right to occupy a site for residential, professional or business purposes $(6, p$ 197)

Water supply is controlled by the Rand Water Board. Control of water pollution is under the Department of Water Affairs, according to the South Africa Water Act 54 of 1956 (6, p 302). The Department of Health, Welfare and Pensions and various provincial administrations also have a legal power to control water pollution. Water consumption in Soweto is very high. According to information given by the Urban Bantu Chambers 15838239960 kilo liters of water were consumed in Soweto between April 1979 and March 1980 (financial year), at a cost of R8 million. Water is used mainly for household purposes. There is no water consumed by farm-animals, nor irrigation except for small gardens.

A sewerage system is used in all areas of Soweto. Dry refuse is placed in dust bins which are emptied free of charge twice a week. The Factories, Machinery and Building Works Act 30 of 1941 will apply to the few factories which will be in operation. Legal machinery for the control of atmospheric pollution is determined by the Atmospheric Pollution Prevention Act 45 of 1965. To aid in the prevention of atmospheric pollution, trees are planted in all open spaces. There are no dumping places within reach of human dwellings. All recreational centres and other public places are supplied with big rubbish bins which are emptied twice a week. Streets, parks and recreational centres are cleaned by a cleaning team employed by WRAB. All premises are inspected every three months by inspectors from WRAB. Fumigation is done frequently, especially in hostels.

Black education is provided by the Department of Education and Training. Free compulsory education has been introduced recently under the Education and Training Act 90 of 1979. Soweto is served by more than 285 schools (primary, secondary, technical and teachers' colleges) with a combined enrolment of more than 185000 pupils $(6, \mathbf{p} 197)$.

In 1980 the State and State aided schools, from lower primary to senior secondary in the whole Johannesburg area had an enrolment of approximately 192937 pupils. This shows that there is a marked increase in the proportion of children at higher educational levels. Nevertheless, counselling programmes at schools have to be approached so as to also be of value to early school leavers $(3, p$ 24).

There are 70 clubs for men, women and children, six libraries and more than 17000 shops in Soweto. There are 303 churches of 70 religious denominations, three big sport stadiums, 345 sports fields, three athletic tracks, 42 tennis courts, two golf courses and 39 playgrounds in full use. There are 64 crèches under WRAB and private organisations $(6, p$ 197).

There is one early learning centre at Moletsane run by a private organisation which admits babies from the age of six months. The centre concentrates on the care and education of the preschool child. For teachers and parents interested in early childhood education free consultation services are also available for all population groups every Tuesday afternoon at the Johannesburg Society for Early Childhood Education (5, p 10).

The control of the eco-system takes into consideration all social problems which may affect health. For instance low literacy levels lead to unemployment, poverty and ill health. The Department of Education and Training has full-time teachers who teach at night schools. Classes are offered from sub-standard to matriculation level.
Environmental education whereby students are made conscious of their environment, has been adopted in the entire system of education, from primary school to university. Regular educational tours bring pupils into close contact with nature $(6, \mathrm{p} 306)$.

The Organic Soil Association of South Africa's Operation Grow help Soweto people by distributing seeds, seedlings, tools and fencing materials to all who wish to start a garden. The aims are to beat soaring food costs and to dramatically improve the environment.

Food Gardens Unlimited, based in Melrose, runs educational projects providing self-help, health and nutrition education as well as creative activity in Soweto $(5, \mathrm{p} 9)$.

Health education talks are also given to various groups by health personnel and voluntary workers (from private or industrial organisations). Changes in attitudes and eliminating certain misconceptions concerning disease and bacteria are the main themes. People are taught to seek early treatment, irrespective of their personal herbalists. The community is not totally barred from going to indigenous healers, but they must realise the im. portance of receiving early medical treatment from their nearest clinics.

Unemployment figures are unreliable because these are provided for the whole Johannesburg area. According to information from the Department of Co-operation and Development 1517 people were unemployed during Scptember 1980. Those who received social security during September 1980 in the whole area of Johannesburg were as follows:

- old age pensioners: 16228 ;

- blind pensioners: 305 ;

- persons receiving disability grants: 6719 ;

- war veterans: 108 ;

- lepers: 2.

The total number of aged in Soweto cannot be estimated because eldery people leave Soweto once they are pensioned and others are self-supporting. The Commissioner for Child Welfare registers approximately ten to fifteen new foster care and maintenance cases per day.

Employment opportunities in Soweto include positions for males and females working for WRAB, the traffic department, fire station, bottle stores, shops, PUTCO and backyard employment such as welding, sewing and shoemaking. The installation of electricity is being done by more than 5000 employees who are mainly on contract for a year. 


\section{HEALTH AND HEALTH SER- VICES}

\section{General}

Strong liquor is Soweto's main social problem. According to the WRAB public relations officer, WRAB bottle stores sold 18784719 liters of beer during the first six months of 1980 . The profit per night from weekend stokvels (parties) is as high as R500,00. Spirit sales came up to 304421 litres between January and June 1980. The abuse of liquor may therefore contribute to increasing antisocial behaviour which includes rape, abuse of drugs, murder and theft. Related figures are not given to the public, according to the Public Relations Officer, Protea police station (Soweto police headquarters). Another social problem is the thousands of litres of various home brews which are consumed and which may be poisonous or lead to ill health.

The general nutritional status in Soweto is fair. Babies who gradually lose weight get a free milk supply and vitamin syrups from the immunisation clinics. Pensioners with no other means of finance receive food parcels from the Social Welfare Department in Johannesburg and from church organisations. School childdren buy fresh fruits and other foods and refreshments from Zozo shops (mobile refreshment stalls) and vendors.

According to Baragwanath hospital's Public Relations Officer the average birth weight ranges between 2,5 and $3,1 \mathrm{Kg}$. The hospital's average daily delivery is between sixty and seventy babies with a total of 26000 babies per year. In spite of the efforts by the Department of Health Welfare and Pensions, in co-operation with other parties, the birth rate for Blacks remains high. Traditional values are undoubtedly responsible for this trend. The rise in birth rates, coupled with a sharp decline in the mortality rate, will contribute to the population explosion (6, p 24).

The utilisation of immunisation programmes is satisfactory or nearly $100 \%$. No Soweto children are admitted to nurseries and schools without their immunisation cards. Utilisation of services by sick people is no problem as most people attend the clinics or are referred to the hospital. There are few private medical practitioners.

Control of communicable diseases is the joint responsibility of the Johannesburg City Health Department and the Transvaal Provincial Administration. City Health Department nurses have their Head Office at the Civic
Centre in Johannesburg. Their contribution includes immunisation, visits to tuberculosis cases, defaulters and contacts. A special clinic is provided for the treatment of venereal disease, including treatment for pregnant women with W.R. positive blood tests. Health education talks are given on nutrition, environmental health and the importance of immunisation. Family planning programmes include the insertion of intra-uterine devices and prescription of other contraceptives.

Services for the rehabilitation of mentally retarded children are provided by the Mental Health Society of the Witwatersrand. The criterium for acimission to a day centre is that the child must be habit-trained. Free transport is provided to and from the centres. Various forms of handcrafts are taught. Voluntary workers also help with the instruction of children.

There is one workshop for the physically handicapped at Orlando East, which is run by WRAB.

Veterinary services are given free of charge. Animals are taken to the Pets Free Hospital (WO 1337) which is run by the People's Dispensary for Sick Animals.

Voluntary health support services are operated in Soweto and from Johannesburg, for instance by the Cripple Care Association, the Child Welfare Society, South African Red Cross Association and many other groups.

Health education is given by all nursing staff in the clinics, hospital and district. All nurses doing a basic diploma in nursing, enrolled nurses and enrolled nursing assistants get guidance on health education Voluntary workers are also trained by professional nurses and give health education according to the needs of families visited. Voluntary workers do not wear a uniform and are not sophisticated and are therefore accepted with greater ease by the community.

Mental health services for all groups consist of after-care services in five Soweto clinics. The Department of Health, Welfare and Pensions supplies nurses, doctors, a clinical psychologist and medicine. The Mental Health Society of the Witwatersrand offers accommodation. The Department of Co-operation and Development supplies social workers and the Government Garage offers transport. Psychiatric services in Soweto are still at the infant stage.

\section{Curative Services}

Health services for the community are provided mainly by Baragwanath Hospital which is the largest Black hospital covering 173 acres and including the St. John Eye Hospital, a midwifery section, a general section, doctors' quarters, a nurses' residence and the nursing college. The hospital treats more than 980000 out-patients annually. There are 68 wards and the hospital has nineteen of the best equipped surgical theatres in the country. There are 2714 beds, inclu sive of midwifery, general and clinic beds. All ward-sisters are Black and the hospital is the major post-registration training centre for Black nurses. Baragwanath Hospital is the biggest specialist hospital in the country and it is known world-wide $(6, p 197)$.

According to the Public Relations Officer, the smooth running of the hospital's services is supported by 3800 registered nurses including matrons, tutors and sisters. Enrolled nurses, enrolled nursing assistants and student nurses bring the total number to 4185 . There are 485 doctors and dentists of all population groups. The total number of paramedical practitioners, including pharmacists, radiographers, physiotherapists, speech therapists, occupational therapists, dieticians and technicians is 387 . The administrative and general staff number 610 and daily paid workers (security guards, cleaners, labourers, messengers, porters and kitchen staff) 1967. The Chief Superintendent is in overall charge of the hospital with the help of deputy superintendents. Lines of communication for all workers are through the sectional heads namely, nurses under the matrons, tutors under the principal, administrative staff under the secretary

The training of professional nurses as primary health care workers contributes to the effective use of services. More people attend clinics because primary health care nurses belong to various ethnic groups. There are no language problems and therefore no interpreters are needed. Nurses are also delegated to district services for chronically ill patients who have been discharged from the hospital. Ambulance services operate between the ten clinics and the hospital and are available for emergency help. Clients who need ambulance services from home, can contact the nearest fire station. The fee paid for an ambulance ranges from $R 1,00$ to $R 2,00$.

\section{Services for the Aged}

Among the numerous health services in Soweto, are the services for the aged which are provided by the Johannesburg Council for the Care of the Aged and other organisations. 
There are four social clubs in different areas which operate between $10 \mathrm{~h} 00$ and $12 \mathrm{~h} 00$ on Mondays and between $11 \mathrm{~h} 00$ and $13 \mathrm{~h} 00 \mathrm{pm}$ on Tuesdays, Wednesdays and Fridays. These centres are within walking distance for the aged. The senior citizens who wish to use public transport, make use of Putco services at minimal cost. Various services such as handcraft, music and teas are provided in the clubs according to the special interests of the members.

Soup kitchens are operated and second-hand clothes are sold for a nominal amount on pension pay-out days. The old age home is still in the planning stage but applications for admission can be made at the Bantu Presbyterian Church, Moroka Township.

Other facilities for the aged are made available by WRAB for instance rent remissions which are provided in part or full, depending on the financial and other circumstances of the particular individual and his family. Special grants, clothing and blankets are provided on merit.

Other services are provided by Baragwanath Hospital such as clinic and dental services, a free ambulance service, and an eye clinic at the St. John Hospital where free tests and free glasses are given to pensioners. Spectacles can also be obtained from Project Bright Sight which is run by Lions International. Artificial limbs, eyes and teeth are supplied free by the Department of Health, Welfare and Pensions through Baragwanath Hospital. District nursing services are also given free to pensioners and other indigent persons.

Various other organisations also provide care for the aged namely: the Anglican Mothers Union who visit pensioners, give food, clothes and blankets; the Black Housewives League who supply refreshments at some pension pay-out points and give Christmas parties; the Black Reformed Church in South Africa and the Roman Catholic church who give help to their distressed aged.

The Black Sash provides a free advice service to Black people who have difficulties with reference books and pass law problems. Services for blind aged Blacks are not available in Soweto but those in need can use various services available to the blind nationally, for instance braille watches, braille printing machines and books on tapes in Bantu languages at the South African Library for the Blind in Grahamstown.
Some supermarkets sell meat packets at a special price to those with buying concessions. The Cripples' Care Association of Transvaal offers home visits, transport, counselling, treatment, training, orthopaedic appliances such as artificial limbs, supervision and after care, wheel chairs and recreation where possible and assistance in obtaining employment. Lions International run a hearing aid bank for indigent aged with hearing defects.

\section{THE FUTURE}

Health service projections include ten day-hospitals to be built, eight poly-clinics to be converted into dayhospitals with about twenty beds each, one general hospital near New Canada Station and one psychiatric hospital.

Financing of health services is provided by the Transvaal Provincial Administration, the Department of Health, Welfare and Pensions, the City Health Department and voluntary donations on an individual basis. Few Soweto citizens are under medical aid schemes. Significant developments that will have a positive effect on the health of the community include:

- the introduction of comprehensive health services which will help coordination of services and may lead to more effective use of available health services:

- self-help services such as the Soweto food gardens will help to curb the rising cost of food;

- changes in the system of education will meet the advances in technology and unemployment figures will decrease;

- houses, hospitals, schools and factories which are to be built will increase employment opportunities and may contribute much to raising the morale of the community;

- if all or most Soweto citizens would accept and practice family planning, there could be a decrease in the population explosion which is being faced;

- general economic development means health, because money can be used to increase facilities and increase the income of the popula. tion;

- installation of electricity will help those on life-saving machines, air pollution problems will be partly solved and the crime rate decreased;
- more transport means obtaining health services without delay;

- more schools as well as compulsory education will lead to a rise in literacy levels. The opening of centres for higher education, namely teachers' colleges, will help to meet the required teacher to pupil ratio of $1: 35$.

\section{CONCLUSION}

The health care delivery system in Soweto tries to enable Soweto citizens (individuals and families) to obtain initial and continuing health care of appropriate quality. Health services are co-ordinated with social and related services to help individuals and their families to face day-to-day problems.

Services should be centralised in order to have an equal distribution of health personnel and workload. There should be a balance in promotive, preventive, curative and rehabilitative health services.

There is also a need for the provision of services to deal with urgent problems. A crisis clinic is necessary, especially during week-ends when murder, attempts of suicide, rape, family quarrels and abuse of alcohol are common.

Depending on progress and community motivation there may be no smoke clouds in Soweto in ten years time. Strangers will touch with warmth and not hositlity. Trees, lawns, flowers and showhouses will add to the beauty. A bright and hygienic environment means healthy people.

BIBLIOGRAPHY

1. Braden, C.J.; Herban, N.L. Community health: a system approach Appleton Century Crofts. New York. 1976.

2. Brandejs, J.F. Health information: Canadian experience North Holland Publishing Company. Amsterdam. 1976.

3. National Institute for Personnel Research, Council fo Scientific and Industrial Research: Careers Coun selling. Vocational Information Services in selling. Vocat

4. Notter, L.E. Essentials of Nursing Research Springe Publishing Co. New York. 1974

5. Opportunity 1980-1981 Johannesburg Council for Adult Edication. Park town.

6. Department of Foreigh Affairs and Information. South Africa 1980/1 Official Yearbook of the Republic of South Africa. Chris van Resnburg Publication Johannesburg. 1980. 7 th edition.

7. Stewart, T.H. An Introduction to Public Health But terworths. Durban. 1971

8. Treece, E.W.: Treece, J.W. Elements of Research in Nursing The C.V. Mosby Company, St. Louis. 1977.

9. Searle, C. Survey of Health Needs of a particular area Tutorial letter no. 102-1980 UNISA Publication. Pre toria. 1980. 